\title{
THE POLICY OF CATHOLIC MONARCHS AND POPES IN THE NEW WORLD ON THE CHRISTIANIZATION OF THE POPULATION AND THE POLICY OF LOCAL AUTHORITIES (1492-1513)
}

(C) 2021

\author{
Ashrafyan K.E. \\ Moscow Region State University (Mytishchi, Moscow Region, Russian Federation)
}

Abstract. The aim was to study the attitude towards slavery and freedom for the natives of the open lands of America on the part of the Spanish Crown, on the one hand, and Christopher Columbus in 1491-1504, and then his son Diego Columbus, appointed governor of Hispaniola in 1508 and became viceroy of the West Indies, on the other. As a result, the texts of the bulls of Pope Alexander VI for May 3 and May 4, September 26, 1493, letters of Catholic Monarchs, letters of Christopher Columbus, letters and orders of Bobadilla and Nicholas Ovando and the events of 1511 in Hispaniola described in the book of Las Casas, as well as documents on the results of the work of the Junta of Burgos in 1512 and the Junta of Valladolid in 1513 were studied and analyzed. The study showed the true and humane attitude of Catholic Monarchs towards the natives of America and the emergence of laws under which the natives of America were granted freedom and equal rights with the Castilians. It also shows the policy of slavery and exploitation set up by the «House of Columbus» against the Indians, and the political battles with the defenders of the Indians from the Dominican Order, that made possible Burgos Laws of 1512 and their amendments - Laws of Valladolid laws of 1513 and their consequences for the freedom and life of the natives.

Keywords: Laws of Burgos 1512; Laws of Valladolid 1513; encomienda; aboriginal slavery; Junta of Burgos 1512; Junta Valladolid.

\section{ПОЛИТИКА КАТОЛИЧЕСКИХ МОНАРХОВ И ПАПСТВА В НОВОМ СВЕТЕ ПО ХРИСТИАНИЗАЦИИ НАСЕЛЕНИЯ И ПОЛИТИКА МЕСТНЫХ ВЛАСТЕЙ (1492-1513 ГГ.)}

(C) 2021

\author{
Ашрафьян К.Э. \\ Московский государственный областной университет \\ (2. Мытищи, Московская область, Российская Федерация)
}

\begin{abstract}
Аннотация. Целью данной работы было изучение отношения к рабству и свободе для местного населения открытых земель Америки с разных сторон. С одной стороны, изучались документы испанской короны, а с другой стороны - местной администрации новых земель: сначала Христофора Колумба в 1492-1504 годах, затем Франсиско де Бобадильи, Николаса де Овандо, Диего Колумба, назначенного губернатором Эспаньолы в 1508 году и ставшего вице-королем Вест-Индии. В результате исследования были изучены и проанализированы тексты булл Папы Александра VI от 3 мая, 4 мая и 26 сентября 1493 года, письма католических королей, письма Колумба, письма и приказы Бобадильи и Николаса Овандо и события 1511 года на Эспаньоле, описанные в книге Лас Касаса, а также документы о результатах работы Хунты Бургоса в 1512 году и Хунты Вальядолида в 1513 году. Исследование показало истинное гуманное отношение испанской короны к туземцам Америки и появление законов, по которым аборигенам Америки предоставлялись свобода и равные права с кастильцами. Также показана политика рабства и эксплуатации, проводимая «Домом Колумба» против индейцев, политические сражения с защитниками индейцев из Доминиканского Ордена, которые сделали возможными законы Бургоса 1512 года и поправки к ним - законы Вальядолида 1513 года. Показаны последствия принятых законов для свободы и жизни туземцев.
\end{abstract}

Ключевые слова: Законы Бургоса 1512 года; Законы Вальядолида 1513 года; энкомьенда; рабство аборигенов; Хунта Бургоса 1512 года; Хунта Вальядолида.

\section{Introduction}

The statement of the problem in general form and its connection with important scientific and practical tasks.

The problem of studying the policy of the Spanish Crown in relation to the natives of the New World is now very relevant and important. This is due to the fact that «black propaganda» and the so-called «Black Legend», which for a long time was directed at Spain by England, France, Holland and other countries, led to the fact that the actual attitude of the Catholic Monarchs to the local population in the newly discovered lands of America of the 15-16 centuries was hushed up or distorted [1, c. 232]. Soviet and new Russian literature, both artistic and scientific, was perverted by the mass consciousness regarding the policies of the Catholic Monarchs, and it was necessary to eliminate bias and study documents to find out the real facts. In this paper we have explored important points and used translations of original documents from Spanish, English, Russian, French and Latin, which shed light on the ongoing war of various political groups in Spain against each other and the impact of this on the local population of the New World. The study shows how judicial and political battles in Spain affected the state and the policy of slavery or freedom towards the Natives by various administrations from 1493 to 1513. This paper is published as the first part of a broad study of the Christianization of the New World in the sixteenth century and its reinterpretation for the world history. 


\section{Innovation}

The novelty of these issues is high, as the subject of the paper is the causal relationship of political and legal battles between the Catholic Monarchs and the «House of Columbus» are rarely raised in scientific literature, especially in Russia and throughout the former Soviet Union-politics in the New World, the policy of the Catholic Monarchs and the «House of Columbus» perceived as a unified whole. However, this misconception must be changed immediately, as it is fundamentally wrong to teach this period as a period of only brutal exploitation of the local population by Spain. It is this urgent problem when considering the issue that we raise in this paper.

The object of this paper is the period of the world history from 1492 to 1513 .

The subject of the research is the political struggle between the Catholic Monarchs and «House of Columbus» from 1492 to 1513 through the prism of relations appointed by the Spanish Crown administrations to the natives of Hispaniola and granting freedom to the Indians of the New World.

\section{Research methodology and methods}

When writing the paper, primary sources and their translations, scientific articles in different languages and from different countries were studied, so the main method was the documentary method, and the method of source studies.

In this research work, content analysis methods were also used: the comparative-historical method, the chronological method and the systematic method of identifying the cause-and-effect relationships of events that occurred in different parts of the world.

\section{Results of the study}

The study revealed a causal relationship and revealed contradictions between the stated policy of Catholic Monarchs and popes and the actions of members of the «House of Columbus» concerning the Christianization of the local population of the West Indies. This, in turn, affected the freedom of the natives and the relations of the Spanish settlers with the local population.

The study also concluded that there was a political and legal confrontation between the «House of Columbus» and Ferdinand II of Aragon. This was the main reason for the passage of the Burgos Laws of 1512 and the Valladolid Laws of 1513 and was used by the Catholic Monarch as a strong political argument against Diego Columbus and his administration. This struggle was resumed first of all by Diego Columbus. Diego contested the succession rights as heir to the rights of his father Christopher Columbus and resumed his father's lawsuits from 1508 and in the so-called «Pleitos Colombinos» case (1492-1541) with the Spanish Crown, where the legal control of all open lands in the New World was disputed. The «humane laws» became possible for aborigines in the 16 century as the result of the internal political struggle in Spain between the Castilian nobility, which supported the «House of Columbus» and Ferdinand II of Aragon.

\section{Discussion}

\section{The main part}

1492-1503

Two of the three ships of Christopher Columbus expedition returned to the Spanish port of Palos on March 15, 1493. They brought news of the discovery of a new passage to India [2, c. $14 ; 3$, c. 17-19]. Columbus brought Indians along with various exotic gifts from new land [3, c. 24].
It becomes known in the Rome about a month and a half later. Alexander VI (Alejandro VI), who took the place of the Pope on August 11 of the same year 1492, writes the first Bull of May 3, 1493 and second Bull of May 4, 1493. The Pope transfers permission of all the lands that are open to the Crown of Castile by Bulls No. 1 and No. 2, which is called «Breve Inter Caetera» and «Menor Inter caetera». The Crown of Castile and Leon at that time belonged to Queen Isabella I of Castile who was the wife of King Ferdinand II of Aragon (Isabella and Ferdinand were from the «House of Trastamara»). The Pope pointed out in this Bulls that the lands transferred to the Castilian Crown were given for «...the elevation of the Catholic faith and the Christian religion and its strengthening and spreading for the salvation of souls and for the humility and conversion of barbarian peoples to this faith» [4, p. 424].

Thus, the condition of the spread of the Catholic faith among the new peoples was the main condition for granting the rights of the kings of Castile to own the open lands.

1496, December 19, in the bull «Si convenit» Pope Alexander VI proclaimed the title of «Catholic Monarchs of Spain» («Reyes Católicos de las Españas») for Kings Isabella I of Castile and Ferdinand II of Aragon for 6 merits that were discussed earlier - December 2, 1496 by the College of Cardinals) [5]. Thus, the Spaniards «raised high the banner of the ideas of Christianization», in which the evangelization of the local population of new open countries allowed new peoples to join the world of Christianity, which meant the spread of Christianity in the world instead of the countries and territories absorbed by Islam, captured by the Ottoman Empire. Therefore, the interest of the Holy See and the Catholic Monarchs in the new peoples who have passed into the bosom of the Catholic Church is understandable. And this was an urgent task, which could only be solved by a broad and peaceful Christianization of the natives of the New World.

However, from the very beginning of his campaigns, Christopher Columbus, who had already visited Guinea (Africa) several times while he lived in Portugal, had before him a pattern of behavior towards Africans in the lands discovered by the Portuguese, which were granted to the Portuguese by the bull of Pope Sixtus IV «Aeterni Regis» of June 21, 1481. The policy of the Portuguese kingdom was to enslave all non-Christian natives in Africa. Christopher Columbus transferred these politics to opened lands.

In his diaries, originally describing the aborigines of the lands he discovered, Christopher Columbus does not talk about the ways of their conversion to the Catholic faith. And after two months in prison, Columbus says of the Indians only that the natives are «...good to command them and make them work, sow, and do all the rest...» [6, c. 42]. And Christopher Columbus wrote immediately after the first trip in a letter to Sanangel and Sanchez writes that the open lands will allow him to give «as many slaves as you want and as many as I am ordered to send, and these slaves will be from among the pagans» $[2$, c. 40$]$.

Thus, we can understand that his main goal was to rule the Aborigines as his subjects, and not to help them convert to Christianity. And Christopher Columbus considered these lands his own, which he would rule for the rest of his life after the surrender of Santa $\mathrm{Fe}$, and he 
looked upon the behavior of the natives as their master, and not as the distributor of Christendom in the West.

It should be noted that the Indians taken and brought to Spain on the first voyage also participated in the second one. And having contracted smallpox in Spain (in Cadiz), they brought it with them to Hispaniola.

Having transferred his Portuguese experience of visiting Guinea to the new lands, Christopher Columbus calculated in his letter that the slave trade could bring a good income. Here are his words: "If the information I have is correct, it is said that you can sell 4,000 slaves and get at least 20 cuentos... In Castile, Portugal, Aragon, Italy, and Sicily, in the islands belonging to Portugal and Aragon, and in the Canary Islands, there is a great demand for slaves; and I think they come in insufficient numbers from Guinea. And slaves from these lands, if they are brought [to the countries mentioned], will cost three times as much as Guinea, as already noted... And even if the slaves died on the way - still not all of them face such a fate...»

The Spanish began a campaign inland against the Caciques and Indians who had previously killed the Spaniards, and on February 17, 1495, they rounded up 1,600 captured natives and sent 500 of them to ships to be sold as slaves to Castile, 200 of whom died during the voyage $[6$, c. 50$]$.

Before his third voyage, Christopher Columbus received instructions from the Catholic Monarchs on April 23, 1497. There are words about converting the natives to the Holy Catholic Faith and bringing them to complete peace and tranquility, and also that the Indians who want to pay the appointed tax will wear a sign about their necks. However, the most important of the instructions is the instruction of June 15, 1597, which states that Columbus had the right to provide settlers with land, forests and water for the construction of gardens, fields and houses. However, the subsoil-land, forest and water had neither civil nor criminal jurisdiction [6, c. 54]. Nevertheless, Christopher Columbus was in no hurry to distribute to the settlers the land that he considered his own.

At the end of August 1498, Christopher sailed for Hispaniola and punished one of the rebellious Caciques and his men. Las Casas wrote that they were loaded to five ships that were to be sent to Castile for sale as slaves. However, going to sea was delayed, and many of the loaded natives died in the holds, and their bodies were thrown overboard [6, c. 5] and before 1499, Columbus sent ships several times. It is known for certain that once he sent a ship with 600 natives for sale, and another with even more on two ships to sell them as slaves to Spain [3, p. 477].

Quite by chance, while in Seville, Queen Isabella witnessed the unloading of slaves from the holds of two ships that arrived from the New World. Deeply shocked by what she saw, she exclaimed: "What right does my admiral have to give to someone of my vassals?» [7, p. 201-202]. After witnessing the unloading of slaves from ships arriving from America, Queen Isabella also issued a special decree of June 20, 1500, «ESCLAVOS de Sevilla, 20 de Junio de 1500» [8], redeemed at the expense of the treasury for the release of 21 Indians which was sold.

Important is the fact of condemning the actions of Columbus, and also the unprecedented step of the Queen Isabella, who at her own expense bought slaves and ordered them to be sent to their homeland - to Hispaniola in the New World with the ship of the newly appointed judge - ruler on May 21, 1499 to Hispaniola - Francisco Bobadilla [3, p. 430]. As follows from the abovementioned decree: «...you already know how, in accordance with our mandate, you have in your power the arrest and exposure of certain Indians who were brought from India and sold in this city and its archdiocese, as well as in other parts of this Andalusia, by order of our Admiral of the said Indies; whom we have now ordered to be released...» [9, p. 542].

From this action, we see that slavery for the Indians was legally abolished by the decree of June 20, 1500 («Cedula de 20 de Junio de 1500») of Queen Isabella [9, p. 48,$542 ; 10$, p. 23].

It was the uncertainty between the Indians and the different views on the relationship between the Natives and the Castilians that became a stumbling block and an important part of local politics, the revolt of both the Natives and the Castilians themselves.

Since Christopher Columbus was in no hurry to distribute land to Castilian settlers, considering them his own, a Castilian revolt broke out against the Genoese Christopher Columbus and his brother - Bartholomew Columbus who was the Governor (Adelantado) of Hispaniola. Catholic Monarchs broke off relations with family of Columbus. This led to the fact that the commander of the Order of Alcantara, Francisco Bobadilla, appointed on May 21, 1499 to replace Christopher Columbus, began (with the consent of the Catholic Monarchs) to create new legal norms of relations and on September 28, 1499, a reconciliation was reached between Christopher Columbus and Francisco Roldan and his supporters [6, c. 57] and land plots were distributed for 102 rebellious settlers with Indians attached to them [4, c. 457]. This marked a new stage in relations between the natives and the Spanish settlers.

In the same year, 1499, after the distribution of land with the Caciques and their Indians living on them for the rebellious Castilians led by Francisco Roldan, more Indians raised uprisings, but those who participated in them or fled from the land were killed or enslaved. Therefore, ships filled with slaves went to Castile [6, c. 57].

Francisco Bobadilla arrived on August 23, 1500 and arranged a trial of the administration of Christopher Columbus and his brother, Bartolome Columbus. As a result, on November 25, 1500, both Columbus were brought to Spain in shackles [11, c. 167; 12]. And although the brothers were released by personal order of Isabella, but the rights that he had according to the «Surrender of Santa Fe in 1492» on the lands opened to them were canceled [11, c. 167].

The Catholic Monarchs removed Francisco de Bobadilla due to mismanagement and appointed Nicholas de Ovando [2, c. 137; 4, c. 458] governor of the Indies on September 3, 1501 [11, c. 167]. Nicholas Ovando [4, c. 462] was also from the Order of Alcantara and became governor of the West Indies from 1502 to 1509 [3, c. 450$]$.

In the instructions of the Catholic Monarchs on September 16, 1501, Nicholas Ovando was prescribed nonviolent conversion of the Indians and the salvation of their souls. It was required that no one should commit violence to the Indians, rob them, or commit any other evil, return their wives and daughters, and allow them to marry Indian women with their consent [6, c. 73]. And in another instruction on September 16, 1501, the Indians were forbidden to have weapons. 
Very important is the question of the attitude towards slavery of the Castilian Crown, which we are considering here, and it should be noted that on March 14, 1502, in a letter of Queen Isabella written in Valencia, there is a phrase about providing an account «...of everything that you will discover, and of the peoples inhabiting the islands and the mainland that you will find. And you should not bring slaves...» [4, c. 437].

On March 20, 1503, the Catholic Monarchs sent instructions to Ovando and the royal Treasurer that the Indians should not be treated as badly as before, that the Indians should be divided into settlements, and that they should be able to live as individuals residing in our kingdoms. The Indian settlement consisted of houses in which the Indians lived with land for farming and ranching. And the Spaniards had to take care of the Indians and protect them from other Spaniards. And if the Indians want to, they work for a fee for other Spaniards [6, c. 75]. Even more interesting is that already in this document it is said that at the church chaplains had to teach Aboriginal children to read, write, peasants and confess, build hospitals for Indians and Christians... and the most important words were that the Indians should be treated as "royal vassals», where marriages between Spaniards and Indians of both sexes are allowed.

On December 20, 1503, an order from Queen Isabella stated that she had received information that the Indians did not want to work, were wandering and did not want to convert to the Catholic faith. So, the Queen ordered the governor of Ovando to make the Indians work, mine gold, etc. Nicholas Ovando, who had already arrived, on the basis of this decree of the Queen, introduced the system of encomienda (repartimiento), in which the land belonged to the state, but was given to the settlers along with the Indians who lived on them. Each of the Spanish-encomienderos was given a certain fixed number of inhabitants from the local population [10, p. $21 ; 13$ ]. Ovando made sure that the work of the Indians was now controlled. The Franciscan friars sided with the Castilian settlers, but taught the Indian boys the language, writing, and customs of the Castilians [6, c. 80]. The violence that Ovando now used to force labor caused Indian uprisings, which were brutally suppressed, and the system took root. However, it (the system) meant the unregulated and uncontrolled activities of the Castilians-encomienderos.

In 1505, Ovando forced the Spaniards to marry local women under the threat of losing everything they had. This led to a strange situation, as married Spaniards considered the lands of their Indian wives to be their own, which was contrary to the policy of the Spanish Crown $[6$, c. $85-86]$. It must be borne in mind that the Indians of the islands never worked. Moreover, they did not work hard - all eyewitnesses and Columbus himself, who arrived in the New World, wrote about this - they did not know the very concept of «hard work», because they live in good conditions always. The environment provided by food all members of society. Hard and exhausting work in mines, fields, and construction led to rapid fatigue and death from physical and moral exhaustion. The golden reserves of islands were had been depleted but the Spain need more and more gold for wars in Europe.

The Indians of Hispaniola built houses for Spaniards, worked in mines, and cultivated the land [6, c. 82]. To make up for the dying and unworkable Indians, an
Ovando decree in the early 1500 s allowed the importation of black slaves [2, c. 283]. as hardier, but they were very expensive.

In 1508, the situation with the shortage of aborigines' workers became tense. But the solution was found by the settlers themselves - they formed and equipped joint expeditions from one to more ships and send them to neighboring islands to capture the Indians, distribute them among themselves on Hispaniola in exchange for the dead and sell the remains of the Indians to other encomienderos [14]. When the procurators of island of Hispaniola asked the Spanish Crown for permission to bring Indians from other islands, they gave such permission, but demanded that settlers which received this new Indians must pay their salaries and not use them as slaves. Thus, the number of Indians that the enomienderos were required to have legally was a constant, and they did not break the law by «de jure». Depending on the intensity of the work and its severity (it was different in the mines and when digging the ground), the Indians died quickly and often. Therefore, sending expeditions for live goods from settlers became more frequent. Ovando redistributed many Indians. And a few Indians who were Christians received the land as well as the Castilian settlers.

In 1508, Nicholas Ovando [2, c. 124] was removed for mistreating the Indians. This is a very important fact, showing the extent and depth of the Spanish Crown's care for the locals.

Interestingly, in 1517, the monk of the Order of Jeronimo wrote that some Christianized Indians who received allotments in 1508 had no incentive to work they did not crave honors and wealth but indulged in idleness and did not engage in agriculture [6, c. 83].

It is important to note that November 26, 1504 died Isabella the Catholic, Queen of Castile, and in her will dated 23 November 1504 (Codicilo de la reina Isabel la Católica, Capítulo XII (Indios, su evangelización y buen tratamiento)) also speaks about the Indians she most earnestly enjoined her successors to treat the Indians in the new possessions beyond the seas with the greatest kindness and gentleness, to redress any wrongs they might justly complain of, and to carry on the sacred work of civilizing them and converting them to Christianity [12, p. 604]: «...our main intention was to try to seduce and inform local residents and to involve them in our Catholic faith, and send the prelates, religious leaders, clergy and other scholars and religious people on these Islands and Tierra, to instruct their neighbors and residents in the Catholic faith...» [12, p. 14; 15].

1508-1513 years

In 1508, Christopher Columbus' son, Diego Columbus, was appointed governor of Hispaniola. In appointing him, King Ferdinand said that he would be governor of Hispaniola as long as it was his, the King's, will. Diego Columbus became ruler only of Hispaniola. But he was no longer the ruler of the West Indies, islands and mainland lands discovered by his father (Christopher Columbus).

This leads to the resumption of the court case for the rights of the «House of Columbus» to all the lands discovered by Christopher Columbus and promised to him and his heirs by the surrender of Santa Fe in 1492 and taken from him in 1499. These were the so-called «Pleitos Colombinos»(1492-1541). This was supports by Castilian aristocrats' families. 
On August 14, 1509, a royal decree stated that the Indians should be distributed for 2-3 years. Each and, in order to avoid an unfair distribution, must have an even number of Indians, so that the royal judges (alcades) number 100 aborigines, a married caballero -80 aborigines, a soldier with his wife -60 aborigines, a peasant 30 aborigines [6, c. 83].

On November 12, 1509, the previous owners were ordered to keep their Indians, as they were working worse due to the change of owners. But the new ownersencomenderos had to hold their new possession due to only brought of the Indians. This prompted an attack on the neighboring islands, from which the Indians were taken as slaves and brought to the encomiendas of Hispaniola. An important fact is that the Castilian Crown was owners of all lands but encomienderos wanted the lands to belong them and they children were allowed for two or three lives $[6$, c. 89$]$ in accordance with the principle of inheritance of Castile - eldest son - daughter - wife [6, c. 90].

The king received many complaints about Diego Columbus, who redistributed the Indians to his supporters, leaving the allotments of his rivals without Indians. Therefore, the situation of the native Indians worsened. Therefore, the king sent royal judges, regidors, and royal clerks to monitor the actions of the Columbus administration and, in effect, redistribute the Indians.

In 1511, in Spain (Seville), a new stage of litigation began between the «House of Columbus» (by Diego Columbus) and Ferdinand II of Aragon. It is known to us as the so-called «Los Pleitos Colombinos» [11, c. 167; 16;
17]. It was as a response to the actions of the Spanish Crown in the West Indies.

Expeditions to the neighboring islands became more frequent, and soon by 1511 there was no local population left on the islands of Lucaios. In such campaigns, the island of Bimini (Isla Beimeni) was discovered, and many other small islands were marked on the map of 1511 by Peter Martyr d'Anghiera (fig. 1) [11, c. 169].

The Franciscan monks supported the administration of Diego Columbus, and their main concern was working with the Spanish settlers. They did not care much about Christianizing the settlers themselves. However, this changed in 1510, when Dominican monks arrived on the island, who immediately adopted the basic doctrine of the policy of Christianization of the natives and became friends of the Indians. The tasks of the Dominican and Franciscan Orders contrasted with each other, and their rivalry led to subsequent events. The Dominicans who arrived began to gather all the evidence against the mistreatment of the natives, whom they considered free vassals of the Spanish Crown (although this combination is extremely contradictory). And with the arrival of Juan Garces, a former fugitive settler who killed his own wife [18, book 3, chapter 86], who repented and went into hiding for several years, the Dominicans were able to record important testimony not from poorly speaking Spanish Indians, but so to speak «first-hand». This gave them the opportunity to publicly oppose the encomienda system, to denounce the Spanish encomienderos and their treatment of subjects and disenfranchised natives.

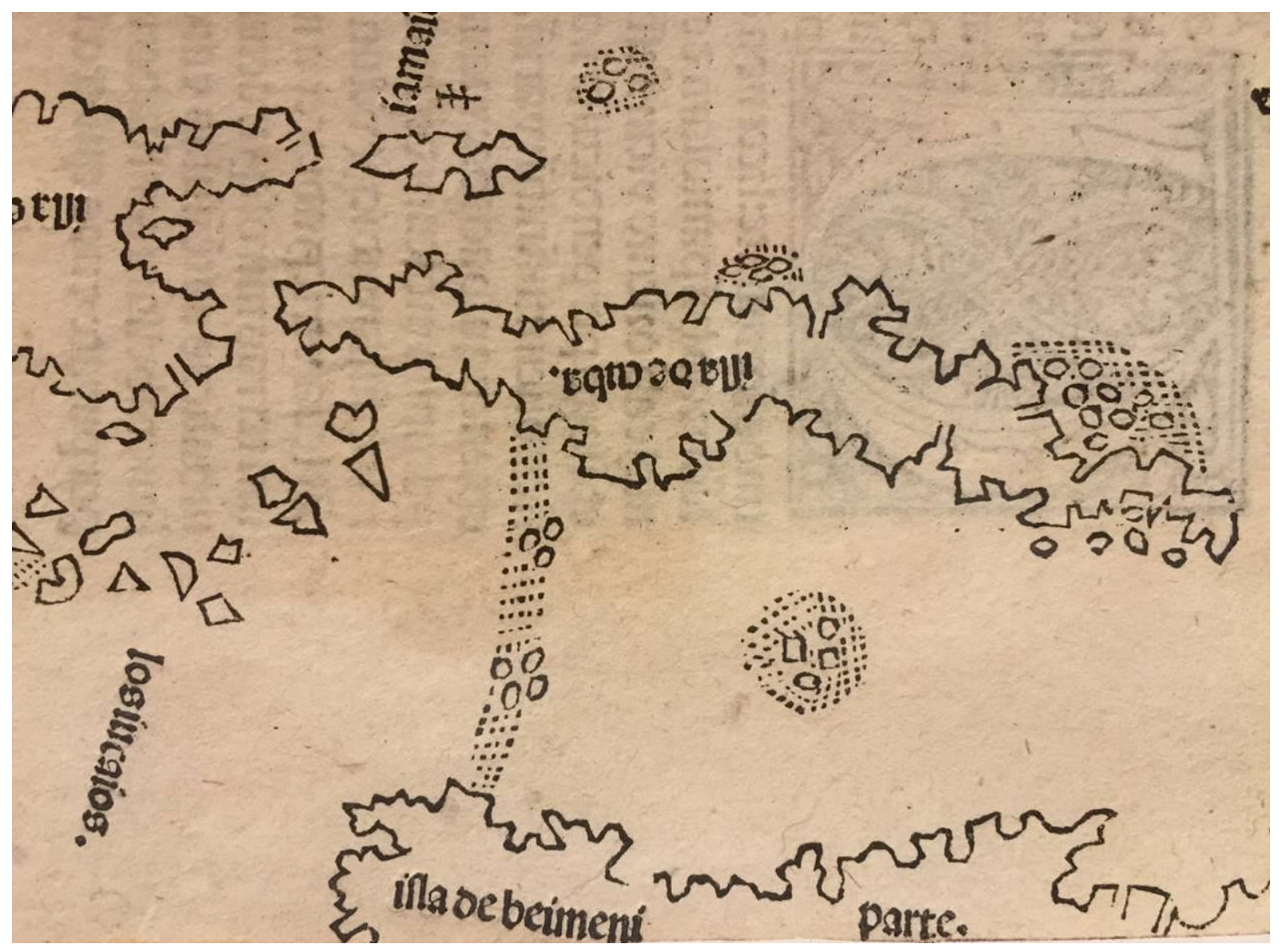

Figure 1 - Island Beimeni (Isla de Beimeni). Photo by K.E. Ashrafyan from Tampa Bay History Center. February 2021. Untitled map of the Caribbean 1511. Andrea Morales.

Published in Peter Martyr d'Anghiera's Opera: Legatio Babylonica Occeani Decas.

Touchton Map Library, Tampa Bay History Center, 2019.125.001. Gift of Arthur and Janet Holzheimer 
In 1511 , an explosion of the society occurred in Hispaniola in the presence of Diego Columbus, during the Sunday mass of the Dominican friar Montesinos. And then again at the next Sunday mass. A blow to the administration of the "House of Columbus» from the church was not expected. It was impossible to change the existing relations and laws: the established production of gold and silver, the construction and cultivation of land, the legal and judicial system acted in the interests of the administration of Columbus and the whole of Spain and to maximize profits. Internal divisions and constant litigation and administrative wars between the royalist parties of the Spanish Crown and the supporters of the «House of Columbus» are one thing. And another thing is the destruction of the system without the alternative of creating a new and effective one in a short time, and even granting additional rights to the local population. Letters were therefore sent to the king, both from the royalists and from the administration of Columbus, requesting the removal of the Dominican friars from the island. Also, from Hispaniola was sent a reverend father from the Franciscan order - Fray Alonso del Espinal [18, book 3, chapter 5]. The king, at first succumbing to the logic set out in letters from Columbus and the Franciscan father, as well as from his treasurer in the West Indies Posamonte about the collapse of the system and the subsequent loss of income for the Spanish Crown, refused to accept the arriving Dominicans.

However, the monk-preacher Montesinos broke through to him. Ferdinand listened to the Dominican. Then the king decided to use the unexpected opportunity for his political purposes, because he was a magnificent and subtle politician. The theme of the unauthorized cruel exploitation of the Indians by the administration of Diego Columbus and their right to freedom was transferred to the Junta (assembly) of theologians, lawyers and members of the Royal Council, which met first in Burgos in 1512 [10, p. 14; 19, p. 355], and then in Valladolid in 1513. It was to people of sufficient influence in society that he was obliged to give his verdict on the existing order in the New World. Twenty sessions of the Junta of Burgos [15]. This led to the appearance of the document known to us as the «Laws of Burgos» ( «Las Leyes de Burgos») [11, c. 168], which from the very beginning was called "Ordenanzas Reales para el buen regimiento y tratamiento de los Indios》 $[13$, p. 16] and became the prototype of modern «human rights».

The condemnation of the cruel policy adopted towards the Natives led to the inevitable condemnation of the administration of the «House of Columbus» and its allies, and it was their inability to lead the West Indies that caused the horror. This also led to the continuation of the laws of Valladolid in 1513 [10, p. 20], which became a continuation of the laws of Burgos in 1512 and finally marked the tilt towards the Spanish Crown in the ongoing trial of the «House of Columbus» (Pleitos Colombinos) [17].

Important laws of Burgos and their additions - the laws of Valladolid put the Indians on the same level as the Castilians [7, p. 203] and obliged the Castilian settlers to engage in the Christianization of the Indians and limited their ability to exploit the Indians, setting many restrictions and rules when they were involved in hard work $[8 ; 13 ; 20$, p. 23]. And then followed the decree of King Ferdinand in 1514 on the full approval of the Spanish Crown of mixed marriages between Indians and Spaniards [21, c. 49].

\section{Conclusion}

After analyzing the primary sources and their translations into various languages, as well as scientific articles and materials on the subject and object of research concerning the issue of slavery on the part of the «House of Columbus», on the one hand, and the Catholic Monarchs and the Popes, on the other, the author came to the following conclusions.

The rights granted to the Crown of Castile by the bull of Pope Alexander VI assumed the Christianization of the Indians as an essential part of the granting of these rights [22, p. 17-20, 943], and this is confirmed in all other Bulls and documents.

Christopher Columbus, who had previously experienced relations with the aborigines of Guinea, transferred the practice of the slave trade and the attitude towards the aborigines from his previous experience and did not comply with the requirements of the Rome and the Catholic Monarchs on the issue of mass Christianization of the population, constantly violating Isabella's order banning the trade of Indians as slaves.

The encomienda system was recommended by the Catholic Monarchs for implementation in Hispaniola. The same system that developed under Nicholas Ovando in 1503 assigned settlers-encomienderos a certain number of local Indians and the land where they lived. The number of Indians depended on the status of the settler. This system encouraged acts of the slave trade and numerous expeditions of Castilian landowners for «live goods» to neighboring islands. However, the encomienda system was a unique legal system, as the land itself (as property) remained with the Spanish Crown.

Diego Columbus organized the expansion of encomiendas in 1509 in favor of his supporters and this let greater exploitation of the enslaved local population. The illegal slave trade and expeditions for live Indians, who were brought in place of the dead from neighboring islands became even more frequent.

The Dominicans, who arrived in Hispaniola in 1510 and took the side of the Indians, revealed numerous facts of abuse of power among the Columbus administration in connection with the brutal exploitation of the natives and demanded an immediate end to the unauthorized Spanish Crown practice of enslaving the Indians instead of Christianization, which was supposed to be carried out by the Columbus administration.

On the side of the administration of Diego Columbus was the Franciscan Order, which opposed itself to the policy of the Dominican Order in the West Indies.

Taking advantage of the moment of confrontation between the Dominican Order and the Order in the New World, the Spanish King Ferdinand II of Aragon was able to condemn the administration of Diego Columbus as not fulfilling its duties and dealt it a strong blow. This blow also fell on the claims of the «House of Columbus» to the lifelong claims of Christopher Columbus and played an important role in the confrontation in court («Pleitos Colombinos») for this issue.

Such a political blow could not be dealt by the king himself in an open confrontation between him and the Castilian aristocracy which supported the House of Columbus, so he called a Junta (assembly) with respected theologians, scholars and members of the royal council. 20 meetings of the Junta of Valladolid led to the conclusion that it was necessary to introduce new laws that would accelerate the Christianization of the aborigines. 
The Dominican friars had their way so that the rights of the natives and their liberties were extended, and it was to the advantage of the king himself to acquire new vassals and put the Indians in the same position as the Castilians who opposed them.

It was a subtle calculation and political game, combined with a correct political assessment of the situation that took place in the West Indies and in the political struggle in Spain between the Castilian Cortes and Ferdinand in 1511-1512, that allowed King Ferdinand II of Aragon to turn the situation in the direction of condemning his opponents - the «House of Columbus» and the Castilian nobility that supported him.

As a result of the laws of Junta of Burgos in 1512 and the Junta of Valladolid in 1513, the world received the most humane laws in the history of the 16 century, abolishing slavery for the Indians and giving them huge rights, while obliging the Spanish-encomienderos to conduct early Christianization among the aborigines.

\section{References:}

1. Светлакова О.А. Монтескье и Испания // Вестник Русской христианской гуманитарной академии. 2019. № 4. C. 231-243.

2. Григулевич И.Р. Крест и меч. Католическая церковь в Испанской Америке, XVI-XVIII вв. М.: Наука, 1977. $296 \mathrm{c}$.

3. Христофор Колумб: Путешествия Христофора Колумба. Дневники, письма, документы. М.: Эксмо, 2008. $512 \mathrm{c}$.

4. Хроники открытия Америки. Новая Испания. Кн. I: Исторические документы. Изд. 1-е. М.: Академический проект, 2000. 496 с.

5. Eusebio Rey S.I. La bula de Alejandro VI otorgando el título de 'Católicos' a Fernando e Isabel // Razón y Fe. 1952. № 146. P. 59-75.

6. Александренков Э.Г. Аборигены Больших Антильских островов в колониальном обществе: Конец XV - середина XVI века. Бельцы: Parmarium Academic Publishing, 2017. $508 \mathrm{c}$.

7. Vallejo Piug F.D. Leyes de Burgos 1512 // Mar oceana: Revista del humanismo español e iberoamericano. 2010. Vol. 27. P. 199-203.

8. 20 Junio 1500 mediante una Real Provisión Isabel la Católica prohíbe la esclavitud [Internet] // Historia.com. El pasado as el cultura. 2017. - https://www.historia.com/ magazine/20-junio-1500-mediante-una-real-provision-prohibela-esclavitud.

9. Andrés-Gallego J. Tres grandes cuestiones de la historia de Iberoamérica: ensayos y monografías: Derecho y justicia en la historia de Iberoamérica: Afroamérica, la tercera raíz: Impacto en América de la expulsión de los jesuítas. Majadahonda: Fundación MAPFRE Tavera, 2005. $1384 \mathrm{p}$.

10. Domingo R.S. Las leyes de Burgos de 1512 y la doctrina jurídica de la conquista // Revista jurídica de Castilla y León. 2012. Vol. 28. P. 1-55.

11. Ашрафьян К.Э. К вопросу об открытии Флориды в 1513 г. // Вестник Московского государственного областного университета. Серия: История и политические науки. 2020. № 2. C. 166-174. DOI: 10.18384/2310-676X2020-2-166-174.

12. Walsh W.T. Isabella of Spain. 5th ed. London: Sheed and Ward, 1935. $644 \mathrm{p}$.

13. Luaces P.G. 1514: Real Cédula que permite el matrimonio mixto, un hecho que destroza la Leyenda Negra [Internet] // Libertad Digital. - https://libertaddigital.com/ cultura/historia/almanaque-de-la-historia-de-espana/1514-realcedula-que-permite-el-matrimonio-mixto-un-hecho-quedestroza-la-leyenda-negra-8880.

14. 1512-1513. The Laws of Burgos [Internet] // Colonial Latin America Chronology. - https://faculty.smu.edu/ bakewell/bakewell/texts/burgoslaws.html.

15. Gómez-Mampaso S.S. Una visión sobre el testamento y el codicilo de Isabel la Católica // Icade. Revista De La Facultad De Derecho. 2004. Vol. 63, № 1. P. 113-152.

16. Cesáreo F.D. Los pleitos de Colón. Introducción // Boletín de la Real Academia de la Historia. 1892. Vol. 20. P. 521-535.

17. Egío García J.L. Columbus's inheritance. A new edition of the (Misnamed) Pleitos Colombinos // Rechtsgeschichte - Legal History. 2017. № 25. P. 347-349. DOI: 10.12946/rg25/347-349.

18. Лас Касас Б. История Индий. Л.: Наука, 1968. $471 \mathrm{c}$

19. Gamazo A.S. Burgos 1512: La ciudad, los hombres y las leyes // Burgos 1512: the city, the men and the laws // XX Coloquio de Historia Canario-Americana: Seminario Canarias-Sevilla-América, Las Palmos de Gran Canaria. Las Palmos de Gran Canaria: Casa de Colon, 2012.

20. Worth J.E. A History of Southeastern Indians in $\mathrm{Cu}$ ba, 1513-1823 // Southeastern Archaeological Conference, Randell Research Center Florida Museum of Natural History. 2004, October. P. 21-23.

21. Волкова Е.Ю. Характер влияния европейской культуры на аборигенную культуру индейцев Южной Америки в XVI в. // Вестник Московского государственного гуманитарного университета им. М.А. Шолохова. История и политология. 2013. № 3. С. 39-50.

22. Hernaez F.J. Colleccion de bulas, breves y otros documentos relativos a la Iglesia de America y Filipinas. Bruselas: Imprenta de Alfredo Vrovant, 1879. 989 p.

\begin{tabular}{|c|c|}
\hline Information about the author(-s): & Информация об авторе(-ах): \\
\hline $\begin{array}{l}\text { Ashrafyan Konstantin Eduardovich, postgraduate } \\
\text { student of Archaeology, History of Ancient World } \\
\text { and History of the Middle Ages Department; Moscow } \\
\text { Region State University (Mytishchi, Moscow Region, } \\
\text { Russian Federation). E-mail: kea6465@gmail.com. }\end{array}$ & $\begin{array}{l}\text { Ашрафьян Константин Эдуардович, аспирант } \\
\text { кафедры археологии, истории древнего мира } \\
\text { и средних веков; Московский государственный } \\
\text { областной университет (г. Мытищи, Московская } \\
\text { область, Российская Федерация). } \\
\text { E-mail: kea6465@gmail.com. }\end{array}$ \\
\hline
\end{tabular}

\section{Для цитирования:}

Ashrafyan K.E. The policy of Catholic Monarchs and Popes in the New World on the Christianization of the population and the policy of local authorities (1492-1513) // Самарский научный вестник. 2021. Т. 10, № 1. С. $230-236$. DOI: 10.17816/snv2021101208. 